\title{
Prenatal Invasive Testing: A 4-Years Single Institution Experience in Turkey
}

\author{
Emre EKMEKÇİ1, Kutlu KURT² ${ }^{2}$, Servet GENÇDAL ${ }^{2}$, Emine DEMİREL ${ }^{1}$, Sefa KELEKÇİ1 \\ Izmir, Turkey
}

ABSTRACT

OBJECTIVE: Evaluation of indications, methods and results of prenatal diagnostic invasive procedures performed in our clinic in a four-year process and interpretation of relations between them.

STUDY DESIGN: In this study 553 patients were examined retrospectively, who were undergone prenatal invasive procedures in our clinic for determination of fetal karyotype. Demographic distribution of the patients, indications for tests and results were examined, complications were evaluated depending on the procedure.

RESULTS: A total of 41 abnormal karyotype pregnancies detected, the most common abnormal karyotype was trisomy 21 and most of abnormal karyotypes were detected in patients who undergone invasive diagnostic tests due to abnormal ultrasound findings. Abortion is resulted at two patients.

CONCLUSION: Although non-invasive prenatal diagnosis is more accessible today and has become more preferable, prenatal invasive diagnosing still remains its importance in prenatal diagnosis. Especially in the cases with presence of abnormal ultrasound findings, invasive prenatal diagnosis should be the primary diagnostic method.

Keywords: Prenatal invasive test, Fetal karyotype, Trisomy 21

Gynecol Obstet Reprod Med 2015;21:123-126

\section{Introduction}

Prenatal karyotyping has become an integral element in perinatology practice due to; common use of screening tests, more effective use of ultrasound in pregnancy and postponing pregnancy in older ages in women life. For this purpose, amniocentesis was the first procedure used and then, with the requirement for sooner diagnosis, chorion villus sampling has become a more commonly used procedure. And then chance of achieving faster results has become available with the study of fetal blood sample that is provided by cordosentesis from fetal umbilical cord. However, this process has resulted to various pregnancy complications. Prenatal karyotyping is the most important factor in counseling to families. Upon detecting an abnormal finding, it is decisive in the continuation or termination of pregnancy. Amniocentesis is the most commonly performed invasive prenatal diagnostic testing due to

\footnotetext{
${ }^{1}$ İzmir Katip Çelebi University Medicine Faculty, Gynecology and Obstetric Department, İzmir

2 İzmir Atatürk Research and Education Hospital, Gynecology and Obstetric Department, İzmir
}

Address of Correspondence: Servet Gençdal

Izmir Atatürk Research and Education Hospital Department of Gynaecology and Obstetrics. Izmir, Turkey servetgencdal@hotmail.com

Submitted for Publication

01. 04.2015

Accepted for Publication:

30. 04.2015 the low risk of complications and ease of procedure. First, in 1950, it was implemented for determination of fetal gender. ${ }^{1}$ Mainly it is preferred at $16-18 .^{\text {th }}$ weeks of pregnancy. Another invasive prenatal procedure is cordosentesis that is usually performed after the $20^{\text {th }}$ week pregnancy, karyotyping is achieved on fetal blood sample. It was applied for the first time in 1983 and entered into routine use after this date. ${ }^{2}$ By the common use of nuchal thickness measurement in prenatal diagnosis recently, it resulted more frequent use of chorion villus sampling (CVS) due to need for diagnosis in earlier gestational weeks. In this procedure that can be performed as early as the $10^{\text {th }}$ week of pregnancy, cytogenetic results can be achieved within 48 hours and culture results can be achieved within 7 days. ${ }^{3}$ Indications of prenatal diagnostic tests can be listed as abnormal screening test results, abnormal ultrasound findings, maternal history of abnormal karyotype pregnancy, family history of hereditary disease and maternal anxiety. Recently, due to postpone of pregnancy to advanced maternal age by women, it resulted applying of age-related anxiety-induced prenatal diagnosis more common.

\section{Material and Method}

This study is included 553 patients who were applied fetal invasive prenatal diagnostic procedures for karyotyping between August 2011 and December 2014. The study is approved by İzmir Katip Çelebi University Ataturk Training and Research Hospital Ethics Committee. All patients were in- 
formed about the procedure, the technique of application, risks and complications of procedures before the application and their informed consent is taken. Patients were classified into four groups according to the indications for fetal karyotyping. Group 1; abnormal screening test results, group 2; abnormal ultrasound findings, group 3; maternal anxiety, group 4; patients with history of abnormal karyotype pregnancy. In our clinic, 11-14 week scan is used primarily in prenatal screening test application. The 11-14 week scan is basically calculated on the basis of combined risk and this test is recommended for all singleton pregnancies. However, tripple test is recommended at $16-18^{\text {th }}$ weeks of pregnancy to patients who did not get combined test for any reason. Invasive testing for fetal karyotyping is recommended to patients who has the combined risk of over $1 / 100$ and tripple test of over $1 / 250$. Patients who accepted invasive prenatal tests were included in the group of abnormal screening test results. Any additional method is not recommended to patients with combined risk of 1/1000 and lower. The presence of regurtitation at tricuspid valve, presence of reverse a wave at ductus venosus Doppler and nasal bone measurements were investigated for the patients with combined risk of 1 / 100-1 / 1000 range. In case of detecting at least one positive finding, invasive prenatal diagnostic test is recommended. Invasive tests are not recommended if all findings are negative. Patients who prompted for prenatal invasive diagnostic test but we did not recommended with the results of screening tests were included in the group of maternal anxiety. Isolated advanced maternal age is not used as an indication for karyotyping. Patients with abnormal karyotype history of previous pregnancies were included abnormal karyotype group. Patients who had pathological ultrasonography finding in follow-up independent from others were included in the abnormal ultrasonographic finding group. Blood group analysis is made to all patients prior to procedure and $300 \mathrm{mcg}$ anti-D immunoglobulin was administered intramuscularly in case of Rh incompatibility. Medison Sonoace $\mathrm{X} 8$ ultrasonography was used in applications. The amniocentesis is performed between $16-20^{\text {th }}$ weeks of pregnancy, cordocentesis is performed between $21-33^{\text {th }}$ week of pregnancy and chorionic villus sampling is performed between 11-14 th weeks of pregnancy. Fetal biometric measurements are taken with a detailed ultrasound examination before the procedure and placental localization is determined. 22 Gauge needle is used in amniocentesis and cordocentesis, 18 Gauge needle is used in chorionic villus sampling. Transplacental pass is avoided during application. In order to ensure antisepsis before the procedure, skin is cleaned with $10 \%$ povidone iodine solution twice and then it is covered. After the ultrasound probe is covered with stretch film then antisepsis is achieved by immersion of it in a $10 \%$ povidone iodine solution. During amniocentesis, the first $2 \mathrm{cc}$ part of amniotic fluid is taken to another syringe and then 20cc sample is collected for test. During cordosentesis, a total 4cc cord blood sample is taken to $1 \mathrm{cc}$ syringes that's acted with heparin, from either free part of umbilical cord or the area that umbilical cord enters to placenta. During chorionic villus sampling, transabdominal approach is used and about $10 \mathrm{mg}$ of fetal tissue is transferred to transport medium by using a $20 \mathrm{cc}$ syringe with help of negative pressure. Transcervical approach is not used. Received genetic materials were sent to the laboratory for culture. Cases were evaluated about age, gestational age, indications, results and complications. Culture success rates calculated. Statistical analysis was performed by MedCalc statistical software (MedCalc Software, Ostend, Belgium).

\section{Results}

A total of 2952 different patients were evaluated during this 4-year period in our perinatology policlinic and the majority of these patients consists of patients who were referred to our clinic because of abnormal findings from other centers. So our prenatal invasive testing ratio was a bit high. Prenatal invasive diagnostic procedures were applied to 560 patients and our rate is $18.9 \%$ for invasive diagnostic procedures in our perinatology policlinic. Cordocentesis is used for 62 patients (11\%), amniocentesis is used for 427 patients $(76.2 \%)$ and chorionic villus sampling is used for 71 patients $(12.6 \%)$. The mean age was $31.6 \pm 6.7$ years $(18-47) .201$ patients $(36.3 \%)$ were over 35 years of age. The rate of abnormal karyotype was $5.6 \%$ in the over 35 years age group. The mean gestational age of our patients was 17 weeks 4 days at amniocentesis, 23 weeks 4 days at cordocentesis and 13 weeks 1 day at chorionic villus sampling group. Culture success rate was $99.2 \%(556 / 560)$. Culture was negative at 3 CVS and 1 cordocentesis patients and tests were repeated for two patients. The other two pregnancies were terminated due to omphalocele and exencephaly. The most common endication was abnormal screening test results $(51.1 \%)$ and the second was abnormal ultrasound finding $(23.9 \%)$ after that (Table 1). A total of 41 (7.3\%) patients had abnormal karyotypes. The most common abnormal karyotype was trisomy $21(\mathrm{n}=18,43.9 \%)$ and Turner Syndrome was the second ( $n=9,21.9 \%)$ (Table 2$)$.

12 abnormal karyotypes were detected in the group of abnormal screening test results (4.1\%). 21 abnormal karyotypes were detected in the group of abnormal ultrasonographic findings (15.6\%). 7 abnormal karyotypes were detected in the group of maternal anxiety $(6.3 \%)$. The two cases with Klinefelter Syndrome was detected in this group and pregnancy is not terminated at these patients. Any abnormal karyotype is not detected in the abnormal karyotype hystory group.

Tablo 1: Distribution of indications for invasive testing

\begin{tabular}{lr}
\hline Indication & Case \\
\hline Abnormal screening test result & 286 \\
Abnormal ultrasound finding & 134 \\
Maternal anxiety & 126 \\
History of abnormal karyotype pregnancy & 14 \\
\hline
\end{tabular}


Tablo 2: Distribution of abnormal karyotypes

\begin{tabular}{lr}
\hline Abnormal Karyotype & Case \\
\hline Trisomi 21 & 18 \\
Turner Syndrome & 9 \\
Trisomi 18 & 8 \\
Trisomi 13 & 2 \\
Klinefelter Syndrome & 2 \\
Tryploidy & 1 \\
$46, \mathrm{XY},+13 \operatorname{der}(13 ; 14)(q 10 ; q 10)$ & 1 \\
\hline
\end{tabular}

\section{Discussion}

Prenatal diagnostic tests are the procedures that we use frequently at obstetric follow-up. Prenatal screening tests are being used for almost all patients because the invasive tests have low applicability due to complications. In addition, some prenatal sonographic markers are defined for improving the diagnostic efficacy of screening tests and reducing false positive rates. The factors that we should consider before a screening test or diagnostic test are false positivity or negativity of the test, procedure-related complications, time to get results and the cost of the tests. Recommendation of invasive prenatal diagnosis due to advanced maternal age over 35 years has expired today. However, maternal anxiety induced prental invasive tests for patients in this age group is being performed very common. In our study, the mean age of the patients who underwent prenatal diagnosis due to maternal anxiety was $34.5 \pm 7.8$. But our maternal anxiety group did not contain only advanced maternal age, in addition to them it contains normal combined test and abnormal triple test resulted patients who underwent invasive tests due to maternal anxiety. Abnormal karyotype rate for maternal anxiety group was found to be $6.3 \%$. Interestingly, abnormal screening test results were less predictive than maternal anxiety in our results. We think the reason for this result is, we have made a detailed fetal ultrasound scanning and fetal cardiac scan to all patients prior to invasive procedures and detected sonographic findings. In addition, we have detected major cardiac anomalies at 6 of 7 patients in maternal anxiety group by fetal cardiac examination before invasive procedures.

In our study, invasive diagnostic tests routinely not administered to pregnant women over 35 years of age. In many studies for patients over 35 years old age, invasive tests rotinely applied and a rate ranging between $1 \%$ and $6 \%$ in this group are reported abnormal karyotype. ${ }^{4}$ The risk of having trisomy 21 fetus is reported as $0,15 \%$ before age 35 and the rsik is $0.76-8.33 \%$ after age $35 .^{5}$

134 patients underwent invasive prenatal testing due to abnormal ultrasound findings. Abnormal karyotype rate in this group was found $15.6 \%$, the highest rate was found in this group and was the most valuable finding in terms of the positive predictive. This finding was same as in many similar stud- ies, abnormal ultrasound findings is reported as the most predictive about abnormal fetal karyotype. ${ }^{6}$

Processing-related pregnancy loss rate was found to be $0.35 \%$ and loss in both pregnancy has occurred after amniocentesis. The reason is probably that the amount of the total of amniocentesis procedures significantly greater number than other processes. Center of Disease Control and Prevention (CDC), reported acceptable fetal loss rate as $0.5 \%$. Risk factors for fetal loss after amniocentesis are increased maternal AFP levels, gestational age, perforation of the placenta, blurred amniotic fluid and multiple needle entries. ${ }^{7}$ It is reported that amniotic fluid leakege is the most important factor pregnancy loss after procedures. ${ }^{8}$ Our both cases did not have any risk factor. Pregnancy loss occured on the $3^{\text {rd }}$ day in one case and on the $5^{\text {th }}$ day in the other. We used 22 Gauge needle at amniocentesis procedure. It is reported in a lot of different studies that procedure related complcations are not different with $20 \mathrm{G}, 21 \mathrm{G}$, and $22 \mathrm{G}$ needles. ${ }^{9}$ Nicolaides et al reported that culture success rate increases with advanced gestational age. Their success rate was $5.26 \%$ before 10 weeks gesttation and $0 \%$ after 13 weeks gestation. ${ }^{10}$

Elimination of the need for invasive tests is not possible at the moment with cell free fetal DNA (cffDNA) detection in maternal serum. Non-invasive prenatal testing, in the current situation (NIPT) is considered as high-sensitivity screening test. It can not be used as a diagnostic test. ${ }^{11}$ Therefore, while it will take a place in prenatal diagnostic testing algorithm with the reduction of costs over time, still invasive testing maintains as gold standard.

\section{Conclusion}

Despite efforts to achieve results with less invasive procedures with developments in technology, there is not a diagnostic test that can take the place of invasive prenatal diagnosis procedures yet. In addition, complication rates are quite low in experienced hands with experience obtained. Especially, a major anomaly detection on ultrasound has a high predictive value for abnormal karyotype.

\section{Prenatal İnvazif Test: Türkiye'de 4 Yıllık Tek Merkez Deneyimi \\ ÖZET}

AMAÇ: Kliniğimizde dört yıllık süreçte uyguladığımız prenatal tanısal invazif işlemlerin endikasyon, metod ve sonuç ilişkilerinin değerlendirilmesi ve yorumlanması.

GEREÇ VE YÖNTEM: Bu süreçte fetal karyotipleme amaçlı kliniğimizde 553 prenatal tanısal invazif işlem gerçekleştirilmiş olup, bu olgular retrospektif olarak değerlendirildi. Hastaların sosyo demografik dağılımları, işlem endikasyonları ve sonuçları incelendi, işlemlere bağlı komplikasyonlar değerlendirildi. 
BULGULAR: Toplam 41 anormal karyotipli gebelik saptanmış en fazla saptanan anöploidi trizomi 21'dir. Ayrıca en fazla anormal karyotip saptanan olgular anormal ultrasonografi bulgusu nedeniyle test uygulanan hastalar olmuştur. İki olguda gebelik kaybı gelişmiştir.

SONUÇ: Non-invazif prenatal tanının günümüzde daha kolay ulaşılabilir olmasına ve giderek daha sık kullanılmaya başlanmasına rağmen prenatal invaziv girişimler günümüzde hala prenatal tanıda önemini korumaktadır. Özellikle anormal ultrasonografi bulgusu nedeniyle prenatal tanı yapılacak olgularda invazif testler primer tanısal metod olmalıdır.

Anahtar Kelimeler: Prenatal invasif test, Fetal karyotip, Trizomi 21

\section{References}

1. Nelson M. M,Emery A. E. H. Amniotic Fluid Cells; Prenatal Sex Prediction and Culture. Br Med J.1970 February 28;1(5695):523-6.

2. Liao C, Wei J, Li Q, Li L, Li J, Li D. Efficacy and safety of cordocentesis for prenatal diagnosis. Int J Gynaecol Obstet 2006 Apr;93(1):13-7.

3. American College of Obstetricians and Gynecologists. Invasive prenatal testing for aneuploidy. ACOG Practice Bulletin 88, Washington, DC: Dec 2007.

4. Taşdemir Ş, Yılmaz M, Şahin İ, Erdem H B, Al R A, Ingeç
M, et al. Amniyosentez ve kordosentez yapilan 1429 olgunun retrospektif analizi. Perinatoloji Dergisi 2014;22 (3):138-141.

5. Ferguson-Smith MA. Prenatal chromosome analysis and its impact on incidence. Br Med Bull 1983;39(4):355-64.

6. Dilek T.U, Pata Ö. Yazıcı G. Arslan M. Tok E. Çayan F. et al. Results and Cost-Effectiveness Analysis of Genetic Amniocentesis Between 2000 and 2005. J Turkish German Gynecol Assoc 2005;6(4);285-289

7. Chorionic villus sampling and amniocentesis: recommendations forprenatal counseling. Centers for Disease Control and Prevention. MMWR Recomm Rep 1995;44 (RR-9):1-12.

8. Sener KT, Durak B, Tanir HM, Tepeli E, Kaya M, Artan S. Klinigimizde 7 Yillik Amniosentez Sonuçlari. Perinatoloji Dergisi 2006;14(4):170-175.

9. Uludag S, Aydin Y, Ibrahimova F, Madazli R, Sen C. Comparison of complications in second trimester amniocentesis performed with $20 \mathrm{G}, 21 \mathrm{G}$ and $22 \mathrm{G}$ needles. J. Perinat Med 2010;38:597-600.

10. Nicolaides KH, Brizot M, Patel F, Snijders RJ: Comparasion of Chorionic villus sampling and amniocentesis for fetal karyotyping at 10-13 weeks gestation. Lancet 1994; 344:435-9.

11. Lo JO. Cori D F. Norton ME. Caughey AB. Noninvasive prenatal testing. Obstetrical \& Gynecological Survey 2014;69(2):89-99. 